PAPER • OPEN ACCESS

Novel helical or coiled flocculator for turbidity reduction in drinking water treatment: a performance study

To cite this article: G H Cahyana et al 2021 IOP Conf. Ser.: Earth Environ. Sci. 623012009

View the article online for updates and enhancements. 


\title{
Novel helical or coiled flocculator for turbidity reduction in drinking water treatment: a performance study
}

\author{
G H Cahyana ${ }^{1 *}$, P Suwandhi², T Mulyani ${ }^{1}$ \\ ${ }^{1}$ Department of Environmental Engineering, Universitas Kebangsaan \\ ${ }^{2}$ Soreang Hospital, Bandung Regency, West Java Province
}

ghcahyana@gmail.com

\begin{abstract}
Helical or spiral coiled flocculator have not been applied in drinking water treatment yet in Indonesia. Only a few articles discussed it with different themes like hydrodynamic, floc characteristics, and performance. This study was done to know the efficiency (performance) of helical flocculator with parameters velocity gradient, pipe, helical diameter, flowrate, detention time, and coagulant dose. The study was divided into two steps: Jar test to determine the optimum dosage of coagulant and flocculation experiments to evaluate the helical flocculator efficiency. Efficiencies were in the range of medium to high. On flowrate, $13 \mathrm{ml} / \mathrm{second}$ was obtained good results for two pipe sizes but different in helical diameters. In a 0.5 inch pipe with $0.8 \mathrm{~m}$ helical diameters, the turbidity reduction efficiencies were $72.4 \%$ and $73.9 \%$, and sediment volume was $18.3 \mathrm{ml}$ and $20.0 \mathrm{ml}$. In a 0.625 inch pipe with $0.4 \mathrm{~m}$ helical diameters, the turbidity reduction efficiencies were $76.7 \%$ and $78.5 \%$, and sediment volume was $14.3 \mathrm{ml}$ and $19.7 \mathrm{ml}$. The optimum velocity gradient about 64.9-69.6 per second, and detention time about 438-649 seconds. The results showed that helical flocculator was effective for floc formation. Flowrate, pipe diameter, helical diameter were three key parameters to perform helical flocculator.
\end{abstract}

\section{Introduction}

Since the 1970s, all PDAM has applied conventional technology in water treatment plant because science and technology have not found an innovative design yet [1]. All PDAM does not have a new design, and the Ministry of Public Works has tended to implement IPA Kedasih (Instalasi Pengolahan Air Keluaran Direktorat Air Bersih). In contrast, the quality of raw water varies widely from one island to another. Water in Java island has much suspended solid and different from Sumatera, Kalimantan, Sulawesi, Papua, where their water is rich with natural organic matter. Natural organic matter (NOM) was more influential than turbidity in controlling the coagulant dose [2]. The best removal efficiency on NOM with spiral clari-flocculator [3].

Since that decade, PDAM has used baffled flocculator both in rectangular and hexagonal. Baffled flocculator is an alternative to mechanical flocculator. Unfortunately, the baffled flocculator has a lot of sediment at its compartment's corners, reducing its performance. However, baffled flocculator is still used today because the consultants who designed flocculator in water treatment projects have not had much knowledge about helical flocculator. Efforts have been made to reduce sediment with helical flocculator, an innovation in drinking water treatment technology. Since the 1980s, there has not been much more research yet published. Some literature used different terms: helical, helicoidal, helix, spiral, 
coiled. All terms have the same meaning and interchangeable. Flowrate, turbidity, and dimension of flocculators were different from each other [4-7] .

In the hydraulic study and fluid dynamics in the flocculation process, it was investigated by Sartori et al. (2014) [8]. Tambo and Hozumi (1979) [9], Tambo and Watanabe (1979) [10] examined floc characteristics and floc strength, but they did not use helical flocculators. In other methods, Carissimi and Rubio (2005) [11] have studied the influence of compressed air on the flocculation process. Oliveira and Teixeira (2017) [12] have researched the performance of helical flocculator for turbidity removal. In Indonesia, there has not been researched yet on this flocculator after Arfandy (1979) [4], Harjoko et al. (1980) [5], but perhaps in different types or different nomenclatur like hydrocyclone [13]. There are some differences in shape, configuration, and process mechanism compared to helical flocculator.

Optimum performance in turbidity removal efficiency, sediment volume, velocity gradient, and detention time is the research objective. Experiments are carried out using two pipe sizes and two helix diameters. A helical flocculator produces less sediment than a baffled flocculator. The circular shape in layers is the advantage of helical flocculator, but it is also difficult to make a circular pipe in layers, especially at a big flowrate. It is more difficult than a rectangular shape or hexagonal baffled flocculator if using a large steel pipe diameter. But it eases to implement in the laboratory with small flowrate and no difficulty in setting the apparatus.

The helical flocculators studied by the authors mentioned above used different pipe sizes and different helix diameters. Sartori et al. (2014) [8] used a helical flocculator in horizontal, but in this study, the helical flocculator was installed vertically. All researchers used laboratory scale with variation in pipe sizes and helix diameters. Researchers used a hose or pipe for helical flocculators. Another objective of this study was on small flowrate compared to previous studies by researchers mentioned. It is hoped that a small flowrate is more applicable to the small community of the city. If a larger flowrate is needed, more than one helical unit can be built and installed parallel. It is an alternative solution for a larger community. This study also runs on medium turbidity concentration i.e. 150 NTU. If the small flowrate's performance is good enough, the results of this research can be widely known and become more popular among consultants and governments.

Therefore, it may enrich academic or scientific information on efficiency (performance), velocity gradient $(G)$, and detention time. The essential thing in the design of a hydraulic flocculator is $G$ value and can be maintained in one compartment. Therefore, it could not breakdown the floc. This is the reason why this hydraulic type is more suitable to be applied in small and relatively constant flowrate. Concerning detention time (td), the flocculator requires more time than the coagulator unit for its floc growth. The typical values written on textbooks are 20-60 minutes or 25-55 minutes $[14,15,16]$.

In addition to pipe diameter, another parameter which also plays an important role is the helical diameter. According to its function, the helical diameter can be adjusted to obtain a large $G$ value at the inlet of the helical flocculator and then decrease gradually to the outlet. The helical position and shape of the flocculator can be arranged with any unit in the water treatment plant. If the water treatment plant (IPAM: Instalasi Pengolahan Air Minum) is equipped with a diffused aerator, the helical flocculator can be installed in circles outside the aerator body. The installation can be horizontal or incline depends on the desired hydraulic effect and artistic consideration [17].

\section{Methodology}

This study's idea development was based on the mechanical energy of water, colloidal, suspended solid, and coagulant to be mixed hydraulically. The flocculators were made of $0.5 \mathrm{inch}$ and 0.625 inch plastic hose. The spiral (helix or helical) diameters were $0.4 \mathrm{~m}$ and $0.8 \mathrm{~m}$. The flow were varied from 5 $\mathrm{ml} / \mathrm{second}, 13 \mathrm{ml} / \mathrm{second}, 25 \mathrm{ml} / \mathrm{second}$ and $45 \mathrm{ml} / \mathrm{second}$. Piezometers were installed to know the headloss due to major and minor losses in a pipe (hose). Parameters observed were detention time, velocity gradient $(\mathrm{G})$, pressure loss (headloss), initial and final turbidity for removal efficiency.

\subsection{Apparatus}

a. Pipe diameter 0.5 inch and 0.625 inch 
b. Raw water storage tank

c. Constant headbox

d. Coagulant tank

e. Supporting rack

f. Raw water flow measuring instrument

g. Coagulant flow measuring instrument

h. Pressure (piezometer)

i. Imhoff cone

j. Imhoff cone supporting static

k. Turbidimeter

1. $\mathrm{pH}$ meter

m. Analytical balance

n. Beaker glass $500 \mathrm{ml}, 1000 \mathrm{ml}$

o. Beaker glass $10 \mathrm{ml}, 50 \mathrm{ml}, 500 \mathrm{ml}, 1000 \mathrm{ml}$

p. Stopwatch and $20 \mathrm{ml}$ syringe spuit

q. 125 watt water pump.

\subsection{Materials}

a. Kaolin for raw water turbidity

b. Aluminum sulfate coagulant

c. Dyestuff, red

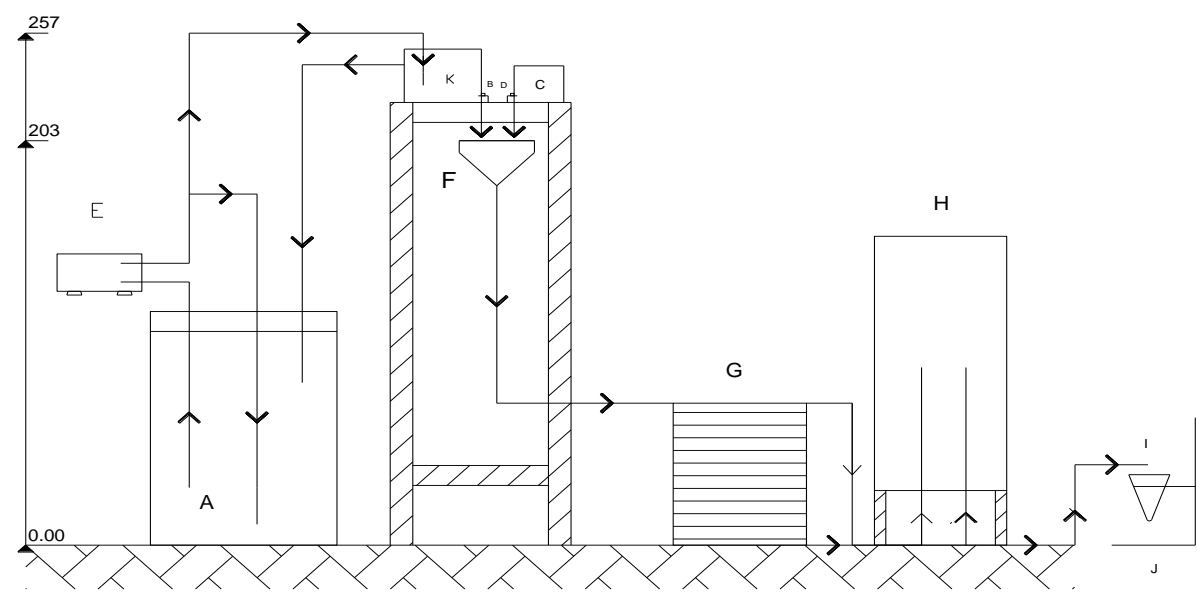

Figure 1. Configuration of helical or spiral coiled flocculator.

\subsection{Helical flocculator}

a. Raw water reservoir

b. Raw water flow measuring instrument

c. Coagulant container

d. The instrument for coagulant flow

e. Pump

f. Mixing raw water + coagulant

g. Helix, helical or spiral coiled flocculator

h. Pressure board

i. Imhoff cone

j. Supporting statif

k. Constant headbox 
A raw water sample was taken and prepared from a groundwater well in Kebangsaan University, Bandung, Indonesia. The turbidity was \pm 150 NTU, made with kaolin suspension, and a stirrer was installed; therefore, the turbidity relatively constant during the experiments.

\section{Results and discussion}

The results were based on 0.5 inch and 0.625 inch pipe diameter with flow variation from $5 \mathrm{ml} / \mathrm{second}$ to $45 \mathrm{ml} / \mathrm{second}$ and 50 meters pipe length. Table 1 shows the results on variation of flow in two sizes of pipe diameter related to type or kind of unit, i.e., coagulation or flocculation process.

Table 1. Comparison of $\mathrm{G}$ (velocity gradient) on each pipe diameter.

\begin{tabular}{cccccl}
\hline $\begin{array}{c}\text { Pipe } \\
\text { Diameter } \\
\text { (inch) }\end{array}$ & $\begin{array}{c}\text { Helix } \\
\text { Diameter } \\
(\mathrm{m})\end{array}$ & $\begin{array}{c}\text { Flow } \\
(\mathrm{ml} / \text { second })\end{array}$ & $\begin{array}{c}\text { G (velocity } \\
\text { gradient) } \\
\text { Theoretical } \\
\left(\text { second }^{-1}\right)\end{array}$ & $\begin{array}{c}\text { G (velocity } \\
\text { gradient }) \\
\text { Experiment } \\
\left(\text { second }^{-1}\right)\end{array}$ & Type of Process \\
\hline & & 5 & 21.9 & 34.3 & Flocculation \\
& 0.4 & 13 & 67.2 & $79.3-80.0$ & Flocculation \\
& & 25 & 144.9 & 165.5 & Coagulation \\
0.5 & 45 & 288.8 & 272.3 & Coagulation \\
& & 5 & 0.8 & $31.5-32.4$ & Flocculation \\
& 0.8 & 13 & 63.2 & $68.7-69.6$ & Flocculation \\
& & 25 & 136.4 & 160.7 & Coagulation \\
& & 45 & 271.9 & 268.1 & Coagulation \\
& & 5 & 11.0 & 28.5 & Flocculation \\
& 0.4 & 13 & 33.8 & $64.9-66.2$ & Flocculation \\
& & 25 & 72.8 & 132.5 & Coagulation \\
0.625 & & 45 & 145.4 & 217.5 & Coagulation \\
& & 5 & 10.4 & 24.7 & Flocculation \\
& & 13 & 31.8 & 59.7 & Flocculation \\
& 0.8 & 25 & 68.5 & 130.9 & Coagulation \\
& & 45 & 136.8 & 203.5 & Coagulation \\
\hline
\end{tabular}

In the coagulation process, the $\mathrm{G}$ value was more than $80 /$ second while flocculation was in the range of 20/second-80/second. Flowrate variation can produce a different performance on helical pipe, namely coagulator or flocculator. At helix diameter $0.4 \mathrm{~m}$ and $0.8 \mathrm{~m}$, both 0.5 inch and 0.625 inch pipe diameter, at flow $25 \mathrm{ml} / \mathrm{second}$ and $45 \mathrm{ml} / \mathrm{second}, \mathrm{G}$ values $=130.9 / \mathrm{second}$ up to $268.1 / \mathrm{second}$. There was a coagulation process in this phenomenon and could be used as a coagulator. At flow $5 \mathrm{ml} / \mathrm{second}$ and 13 $\mathrm{ml} / \mathrm{second}$, it was obtained $\mathrm{G}$ values $24.7 /$ second up to $80.0 / \mathrm{second}$; therefore, the $\mathrm{G}$ value in the range of flocculation process and could take action as a flocculator.

\subsection{Jar test}

Determine the optimum dosage of coagulant needs Jar test was carried out on raw water with turbidity \pm 150 NTU. It was done several times to have an optimum dose. From the series of experiments obtained, the optimum coagulant dose for turbidity $\pm 150 \mathrm{NTU}$ was $220 \mathrm{mg} / \mathrm{l}$ alum $\left(\mathrm{Al}_{2}\left(\mathrm{SO}_{4}\right)_{3}\right)$, and turbidity reduction efficiency was $98.63 \%$, as presented in table 2 . The results of the Jar test were used as an approach to experiments on helical flocculators. 
Tabel 2. Turbidity, coagulant dose, and efficiency.

\begin{tabular}{ccc}
\hline $\begin{array}{c}\text { Turbidity } \\
\text { NTU }\end{array}$ & $\begin{array}{c}\text { Coagulant } \\
\text { Dose, mg/l }\end{array}$ & $\begin{array}{c}\text { Efficiency } \\
\%\end{array}$ \\
\hline 153 & 300 & 78.89 \\
158 & 265 & 98.46 \\
156 & 220 & $98.63^{*}$ \\
152 & 220 & 95.52 \\
152 & 190 & 93.95 \\
\hline
\end{tabular}

\subsection{Results on flocculation}

Helical flocculation experiments with turbidity \pm 150 NTU was applied for two pipe diameters: 0.5 inch and $0.625 \mathrm{inch}$, with helix diameters: $0.4 \mathrm{~m}$ and $0.8 \mathrm{~m}$. There were two flowrates: $5 \mathrm{ml} / \mathrm{second}$ and 13 $\mathrm{ml} / \mathrm{sec}$ nd applied to $50 \mathrm{~m}$ pipe length of helical flocculators. The ability of flocculators was compared to Jar test results that were used as standard. Flocculator, which had turbidity reduction efficiency close to or greater than turbidity reduction efficiency in the Jar test, was called as good flocculator. While flocculator in which turbidity reduction efficiency was smaller than turbidity reduction efficiency in the Jar test was named worse flocculator.

The following data presented the efficiency of turbidity reduction on helical flocculators with helix diameters $0.4 \mathrm{~m}$ and $0.8 \mathrm{~m}$ in two pipe diameters: $0.5 \mathrm{inch}$ and $0.625 \mathrm{inch}$, and flowrate $5 \mathrm{ml} / \mathrm{second}$ and $13 \mathrm{ml} / \mathrm{second}$. The recapitulation of the data observed was presented in table 3.

Table 3. Recapitulation of serial experiments on the flocculation process.

\begin{tabular}{cccccccc}
\hline $\begin{array}{c}\text { Pipe } \\
\text { diameter } \\
\text { inch }\end{array}$ & $\begin{array}{c}\text { Helix } \\
\text { diameter } \\
\mathrm{m}\end{array}$ & $\begin{array}{c}\text { Flowrate } \\
\mathrm{ml} / \mathrm{s}\end{array}$ & $\begin{array}{c}\text { Tur- } \\
\text { bidity } \\
\text { NTU }\end{array}$ & $\begin{array}{c}\text { Td } \\
\text { seconds }\end{array}$ & $\begin{array}{c}\mathrm{G} \\
1 / \text { second }\end{array}$ & $\begin{array}{c}\text { Efficiency } \\
\%\end{array}$ & $\begin{array}{c}\text { Sediment } \\
\text { Volume } \\
\mathrm{ml}\end{array}$ \\
\hline 0.5 & 0.4 & 5 & 151 & 1,110 & 34.3 & 56.7 & 15.7 \\
0.5 & 0.4 & 5 & 152 & 1,110 & 34.3 & 55.0 & 14.0 \\
0.5 & 0.4 & 13 & 158 & 450 & 79.3 & 72.2 & 0 \\
0.5 & 0.4 & 13 & 153 & 450 & 80.0 & 71.8 & 0 \\
0.5 & 0.8 & 5 & 154 & 985 & 31.5 & 91.4 & 0 \\
0.5 & 0.8 & 5 & 159 & 985 & 32.4 & 91.3 & 0 \\
0.5 & 0.8 & 13 & 154 & $438^{*}$ & $68.7^{*}$ & $73.9^{*}$ & 20.0 \\
0.5 & 0.8 & 13 & 152 & $438^{*}$ & $69.6^{*}$ & $72.4^{*}$ & 18.3 \\
0.625 & 0.4 & 5 & 156 & 1,410 & 28.5 & 91.1 & 0 \\
0.625 & 0.4 & 5 & 152 & 1,410 & 28.5 & 91.5 & 0 \\
0.625 & 0.4 & 13 & 153 & $645^{*}$ & $64.9^{*}$ & $78.5^{*}$ & 19.7 \\
0.625 & 0.4 & 13 & 151 & $645^{*}$ & $64.9^{*}$ & $76.7^{*}$ & 14.3 \\
0.625 & 0.8 & 5 & 151 & 1,335 & 24.7 & 94.0 & 0 \\
0.625 & 0.8 & 5 & 155 & 1,335 & 24.7 & 93.6 & 0 \\
0.625 & 0.8 & 13 & 154 & 565 & 59.7 & 77.4 & 2.0 \\
0.625 & 0.8 & 13 & 157 & 565 & 59.7 & 77.0 & 2.2 \\
\hline
\end{tabular}

Flowrate $5 \mathrm{ml} / \mathrm{second}$ on $0.5 \mathrm{inch}$ and 0.625 inch pipe diameter flocculators as well as on $0.4 \mathrm{~m}$ and $0.8 \mathrm{~m}$ helix diameter gave bad results because all flocculators did not show any floc sediment in Imhoff cone. This happened because the detention time was too long, and its velocity was small enough so that the floc was settled inside the flocculator. At flowrate, $13 \mathrm{ml} / \mathrm{second}$ generally showed good results in both pipe diameters. The best result happened on the flocculator 0.5 inch pipe with 0.8 helix diameter. Turbidity reduction efficiencies in this helical flocculator were $72.4 \%$ and $73.9 \%$, with sediment volume 
was $18.3 \mathrm{ml}$ and $20.0 \mathrm{ml}$. Turbidity reduction efficiencies on flocculator with pipe diameter $0.625 \mathrm{inch}$, $0.4 \mathrm{~m}$ helix diameters were $76.7 \%$ and $78.5 \%$, and sediment volume was $14.3 \mathrm{ml}$ and $19.7 \mathrm{ml}$.

Evaluated from helix diameters, the best results also occurred on flocculator 0.5 inch diameter with $0.8 \mathrm{~m}$ helix diameter and on flocculator 0.625 inch diameter with $0.4 \mathrm{~m}$ helix diameter. This happened because of the different flowrates at each helix diameter that can determine the quality of floc formed. The flocculator had turbidity reduction efficiency close to turbidity reduction efficiency in the Jar test and had sediment volume exceed the sediment volume in the Jar test, which means it could meet the requirement as a good flocculator. G value's optimum performance in the range of 64.9-69.6 per second and detention time between $438-645$ seconds.

\section{Conclusion}

The flocculation process occurred effectively in helical (helix) spiral coiled pipe with velocity gradient (G) about 64.9-69.6 per second and detention time in the range of 438-649 seconds. The helical flocculator efficiencies were in the range of moderate to high. On flowrate $13 \mathrm{ml} / \mathrm{second}$ was obtained good results on two pipe diameter sizes: 0.5 inch pipe with helix diameter $0.8 \mathrm{~m}$, turbidity reduction efficiencies were $72.4 \%$ and $73.9 \%$, and sediment volume was $18.3 \mathrm{ml}$ and $20.0 \mathrm{ml}$. On 0.625 inch pipe with $0.4 \mathrm{~m}$ helix diameter was obtained, turbidity reduction efficiencies were $76.7 \%$ and $78.5 \%$, and sediment volume was $14.3 \mathrm{ml}$ and $19.7 \mathrm{ml}$. On flowrate $5 \mathrm{ml} / \mathrm{second}$, worse results were obtained because sediment occurred in flocculators. Also, it can be concluded that the performance of helical flocculator depends on three key parameters, i.e., flowrate, pipe diameter, and helical diameter.

\section{References}

[1] Cahyana G H 2004 PDAM Bangkrut? Awas Perang Air (Bandung: Sahara Golden Press)

[2] Edzwald J K 1993 Wat. Sci. Tech. 27(11) 21-35

[3] Ashery A F, Kamal R and Rashed M G 2012 Proc. Sixteenth Int. Water Tech. Conf. (Istambul Turkey) 16

[4] Arfandy M 1979 Mise Au Point D'Une Methode De Controle En Continu Des Procedes De Floculation-Decantation (France: Doctor dissertation USTL)

[5] Harjoko R, Arfandy M, Tokkong H and Widjanarko E 1980 Proses Floculation dalam Pipa Helikoidal (ITB: Penelitian ITB)

[6] Vigneswaran S and Setiadi T 1986 Water, Air, and Soil Pollution, 29165 - 88

[7] Hameed M S, Muhammed T J and Sapre A A 1995 Filtration and Separation 63-8

[8] Sartori M, Oliveira D S, Teixeira E C, Rauen W B and Reis N C 2014 J. Braz. Soc. Mech. Sci. Eng.

[9] Tambo N and Hozumi H 1979 Water Research 13 441-8

[10] Tambo N and Watanabe Y 1979 Water Research 18(6) 693-707

[11] Carissimi E and Rubio J 2005 Inter. J. Miner. Process 75 237-47

[12] Oliveira D S and Teixeira E C 2017 Water SA 43(3) 378-86

[13] Huda S and Masduqi A 2019 Envirosan Journal 2(2)

[14] Reynolds T D and Richards P A 1996 Unit Operation and Processes in Environmental Engineering (Washington: Int. Thomson Pub)

[15] Droste R L and Gehr R L 1997 Theory and Practice of Water and Wastewater Treatment (New York: John Wiley \& Sons, Inc)

[16] Tchobanoglous G, Burton F L and Stensel H D 2003 Wastewater Engineering, Treatment and Reuse (New York: Mc Graw Hill)

[17] Cahyana G H 2006 Majalah Air Minum 135 50-1 